Original Research Article

\title{
Pharmacological evaluation of substituted 4, 5-diphenyl furan-3- carboxamide compound for antidepressant activity in mice
}

\author{
Jayakumar J. K. ${ }^{1}$, Nityakarnam ${ }^{2}$, Kishore Kumar P. $^{3}$, Supriya $^{4}$
}

\begin{abstract}
${ }^{1}$ Department of Pharmacology, Sambhram Institute of Medical Sciences and Research, Kolar Gold Fields, Kolar, Karnataka, India

${ }^{2}$ Department of Pharmacology, Adhiparasakthi Institute of Medical Sciences and Research, Tamilnadu, India

${ }^{3}$ Department of Pharmacology, PES Institute of Medical Sciences and Research, Kuppam, Andhra Pradesh, India ${ }^{4}$ Department of Pharmacology, Sri Sai Dental College and Research Institute, Srikakulam, Andhra Pradesh, India
\end{abstract}

Received: 21 November 2016 Accepted: 24 November 2016

*Correspondence to: Dr. Jayakumar J. K., Email:drjkshapur@gmail.com

Copyright: () the author(s), publisher and licensee Medip Academy. This is an openaccess article distributed under the terms of the Creative Commons Attribution NonCommercial License, which permits unrestricted noncommercial use, distribution, and reproduction in any medium, provided the original work is properly cited.

\begin{abstract}
Background: Depressive disorder is a prevalent psychiatric disorder, which affects $21 \%$ of the world population. Many drugs are available as effective antidepressants. But still there is necessity of developing novel compounds with minimized side effects. Hence this study was aimed to investigate the antidepressant activity of novel furan compound in albino mice.

Methods: Antidepressant activity of novel furan compound was investigated by using forced swimming test (FST) and tail suspension test (TST) models. Fluoxetine was used as standard drug in this study.

Results: It has been observed from our study that medium dose of test compound $(10 \mathrm{mg} / \mathrm{kg})$ reduced duration of immobility time to 35 seconds when compared to control group (147 seconds) in FST model. In TST model, the test compound of medium dose $(10 \mathrm{mg} / \mathrm{kg})$ had produced $83 \%$ protection against passive behaviour which is almost similar to standard drug fluoxetine (100\%).

Conclusions: The results of the specifies that compared to other two doses of test compound $(5 \mathrm{mg} / \mathrm{kg}$ and $20 \mathrm{mg} / \mathrm{kg}$ ), medium dose of test compound found as an effective dose for treating depression produced due to stress. However, further expansion of the study is needed for this compound to prove as a novel effective antidepressant compared to other drugs available for treating depression.
\end{abstract}

Keywords: Antidepressant activity, FST, Novel furan compound, TST

\section{INTRODUCTION}

The World Health Organization (2010) estimates that 151 million people suffer from depression and around 844 thousand people die by suicide every year. Globally mental health conditions account for $13 \%$ of the total burden of disease and $31 \%$ of all years lived with disability. More than $80 \%$ of the global burden of disease due to mental health conditions can be found in low- and middle-income countries. ${ }^{1}$ 
Depression is a state of low mood and aversion to activity that can affect person's thoughts, behavior, feelings and physical well-being. ${ }^{2-6}$ Patients with major depression have symptoms related to changes in brain monoamine transmitters, specifically dopamine, serotonin, and norepinephrine. ${ }^{7}$

In spite of the availability of many anti-depressant drugs, depression continues to be a major medical problem., Newer generations of antidepressants have provided pharmacologic interventions that are effective and better tolerated than older agents. Even though, there is always a need for the development of new drugs for the treatment of depression as the existing classes of antidepressants are associated with several limitations like adverse effects, delay in the onset of antidepressant action, poor response in certain individuals, etc. ${ }^{10}$

The development of newer and safer therapeutic agents would benefit the treatment modalities of depression. In this study, a novel substituted furan derivative is synthesized and aimed to found its antidepressant activity at $5-20 \mathrm{mg} / \mathrm{kg}$ in mice by using forced swimming test (FST) and tail suspension test (TST).

\section{METHODS}

\section{Animals}

Swiss albino male mice weighing 20-25 g were selected for the study and maintained for 7 days in the animal house under standard laboratory conditions. The animals were fed with standard rat pellet and water ad libitum. The animals were allowed to acclimatize to the laboratory conditions. All procedures were performed during the light phase of the cycle. All the experiments were conducted after obtaining permission from the Institutional Animal Ethics committee.

\section{Antidepressant activity}

The synthesized test compound was screened for antidepressant activity by tail suspension method and forced swimming test in albino mice. ${ }^{11,12}$ A total of 60 mice were selected for the study, 30 mice in each method. Animals were divided into five groups consisting of 6 animals in each. Test drug should be suspended in $10 \%$ Tween80 solution just before administration to the animals. The grouping of animals was as follows:

- Control group received $10 \%$ tween 80 orally

- Standard group received fluoxetine $20 \mathrm{mg} / \mathrm{kg}$ orally

- Test group 1 received $5 \mathrm{mg} / \mathrm{kg}$ substituted furan compound orally

- Test group 2 received $10 \mathrm{mg} / \mathrm{kg}$ substituted furan compound orally

- Test group 3 received $20 \mathrm{mg} / \mathrm{kg}$ substituted furan compound orally

\section{Forced swim test (FST)}

Depression was produced in albino mice by forcing them to swim individually in a glass jar $\left(25 \times 12 \times 25 \mathrm{~cm}^{3}\right)$ containing fresh water of $15 \mathrm{~cm}$ height and maintained at $25^{\circ} \mathrm{C}\left( \pm 3^{\circ} \mathrm{C}\right)$. After an initial 2 minute period of vigorous activity, each animal assumed a typical immobile posture. A mouse was considered to be immobile when it remained floating in the water without struggling, making only minimum movements of its limbs necessary to keep its head above water. The total duration of immobility was recorded during the next 4 min of total 6 min test. A decrease in the duration of immobility is indicative off an antidepressant like effect. Duration of immobility is measured in controls and animals treated with various doses of a test drug or standard.

Duration of immobility $=\frac{\text { Standard }- \text { control }}{\text { Control }} \times \mathbf{1 0 0}$

\section{Tail suspension test (TST)}

Mice are housed in plastic cages for at least 10 days prior to testing in a $12 \mathrm{~h}$ light cycle with food and water freely available. Animals are transported from the housing room to the testing area in their own cages and allowed to adapt to the new environment for $1 \mathrm{~h}$ before testing. Groups of 6 animals are treated with the test compounds or the vehicle orally $60 \mathrm{~min}$ prior to testing. For the test the mice are suspended on the edge of a shelf $58 \mathrm{~cm}$ above a table top by adhesive tape placed approximately $1 \mathrm{~cm}$ from the tip of the tail. The duration of immobility is recorded for a period of $5 \mathrm{~min}$. Mice is considered immobile when they hang passively and completely motionless for at least $1 \mathrm{~min}$. The percentage of animals showing the passive behaviour was counted and compared with vehicle treated controls.

\section{Statistical analysis}

Values obtained for forced swimming test was given as mean \pm SD. All the groups were analysed by one-way ANOVA followed Dunnet's multiple comparison test. P $<0.05$ was considered statistically significant. The values obtained in tail suspension test were given as percentage of animals protected against passive behaviour.

\section{RESULTS}

\section{Forced swimming test}

Table 1 shows the duration and percentage inhibition of immobility time in mice treated with tween 80, fluoxetine, low dose $(5 \mathrm{mg} / \mathrm{kg})$, medium dose $(10 \mathrm{mg} / \mathrm{kg})$ and high dose $(20 \mathrm{mg} / \mathrm{kg})$ of test compound. The animals that received medium dose showed significant reduction in immobility time $(35.83 \pm 9.867$ seconds) compared to control group (147.33 \pm 8.589 seconds). 
Table 1: Effect of test compound on duration and percentage inhibition of immobility in mice by FST method.

\begin{tabular}{|lll|}
\hline Group & $\begin{array}{l}\text { Mean } \\
(\mathrm{sec}) \pm \mathrm{SD}\end{array}$ & $\begin{array}{l}\% \\
\text { Inhibition }\end{array}$ \\
\hline $\begin{array}{l}\text { Control (10\% tween } \\
80 \text { orally) }\end{array}$ & $147.33 \pm 8.589$ & \\
\hline $\begin{array}{l}\text { Standard (fluoxetine } \\
20 \mathrm{mg} / \mathrm{kg} \text { orally) }\end{array}$ & $27.83 \pm 3.869^{\mathrm{a}}$ & 81.08 \\
\hline $\begin{array}{l}\text { Test group-1 (test drug } \\
5 \mathrm{mg} / \mathrm{kg}, \text { orally) }\end{array}$ & $54.00 \pm 8.075^{\mathrm{b}}$ & 63.30 \\
\hline $\begin{array}{l}\text { Test group-2 (test drug } \\
10 \mathrm{mg} / \mathrm{kg} \text {, orally) }\end{array}$ & $35.83 \pm 9.867^{\mathrm{a}}$ & 75.65 \\
\hline $\begin{array}{l}\text { Test group-3 (test drug } \\
20 \mathrm{mg} / \mathrm{kg}, \text { orally) }\end{array}$ & $41.67 \pm 9.74^{\mathrm{a}}$ & 71.69 \\
\hline $\begin{array}{l}\text { a }=\mathrm{P}<0.05 \text { and considered as significant when compared with } \\
\text { control; b = P <0.001 and considered as significant when } \\
\text { compared with control. }\end{array}$ & \\
\hline
\end{tabular}

\section{Tail suspension test}

Figure 1 shows the percentage number of animals showing passive behaviour. None of the animals that received fluoxetine did not show any passive behaviour $(0 / 6) .66 .6 \%$ of animals $(4 / 6)$ that received low dose of drug $(5 \mathrm{mg} / \mathrm{kg})$ showed passive behaviour. The group of animals that received medium $(10 \mathrm{mg} / \mathrm{kg})$ and higher dose $(20 \mathrm{mg} / \mathrm{kg})$ exhibited passive behaviour by $16.66 \%$ $(1 / 6)$ and $33.33 \%(2 / 6)$ respectively.

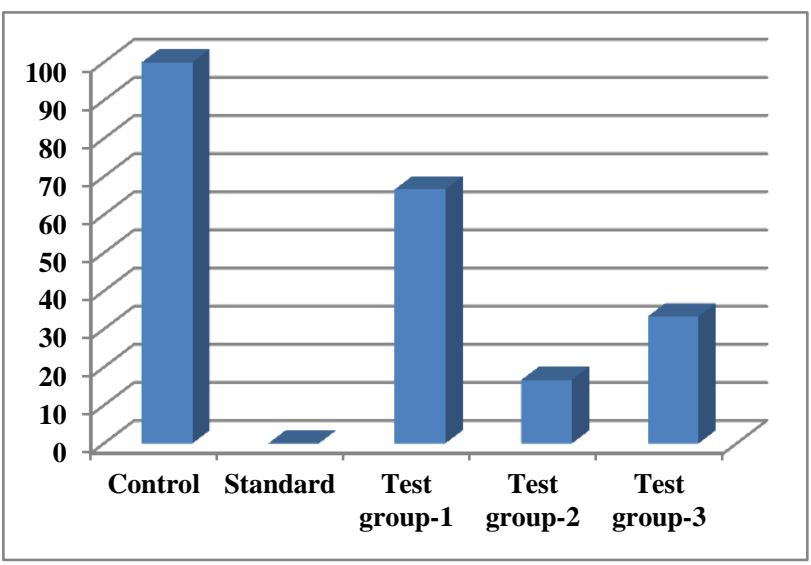

Figure 1: Percentage of animals showing passive behaviour.

Figure 2 shows the percentage number of animals protected against passive behaviour in mice after treating with tween 80 , Fluoxetine, low dose $(5 \mathrm{mg} / \mathrm{kg})$, medium dose $(10 \mathrm{mg} / \mathrm{kg})$ and high dose $(20 \mathrm{mg} / \mathrm{kg})$ test compound. The animals that received medium dose of test compound had shown $83.3 \%$ protection $(5 / 6)$ against passive behaviour that was almost similar to group of animals that received fluoxetine $100 \%$ (6/6). Animals treated with high and low dose of test compound exhibited $66.66 \%(4 / 6)$ and $33.33 \%(2 / 6)$ of protection against passive behaviour respectively.

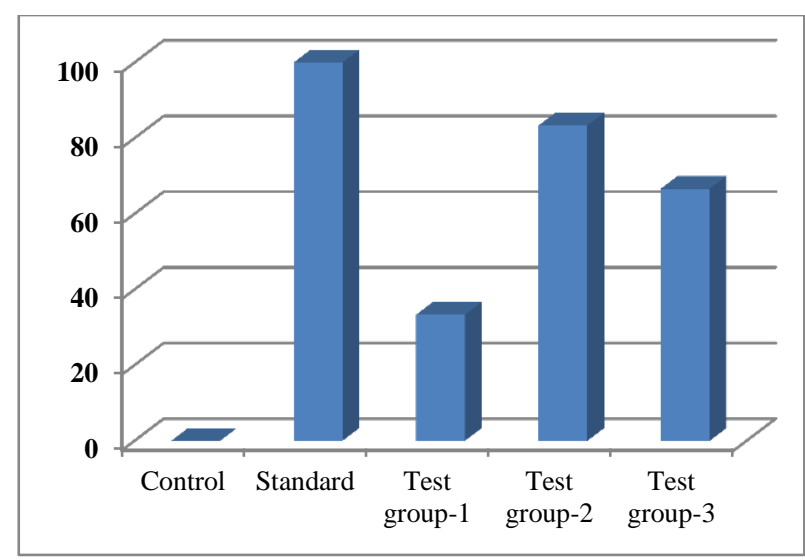

Figure 2: Percentage of animals protected against passive behaviour.

\section{DISCUSSION}

The present study was conducted to assess the antidepressant activity of novel furan compound in albino mice by using FST and TST methods. Stress plays an important role in developing depression. ${ }^{13}$ FST and TST animal models create physical stress and there by leading to depression. These models of depression provide a rapid and reliable behaviour screening test for antidepressants. The immobility has been expected to reflect a state of behavioural despair and failure to adapt to the stress. ${ }^{14}$ Antidepressant drugs decrease immobility time in both FST and TST. ${ }^{15}$

Fluoxetine was used as standard drug in this study in both models because it acts by selectively inhibiting reuptake of serotonin. ${ }^{16}$ The antidepressant activity of the test drug evaluated in this study was a novel furan compound. A number of furan compounds were proved of having significant antidepressant activity. In this study the test drug showed a significant antidepressant activity when compared with control group in both the models.

In the FST the percentage decrease in the immobility duration in mice treated with tween 80 , fluoxetine, low dose $(5 \mathrm{mg} / \mathrm{kg})$, medium dose $(10 \mathrm{mg} / \mathrm{kg})$, high dose $(20$ $\mathrm{mg} / \mathrm{kg}$ ) were evaluated. The fluoxetine had shown maximum efficacy of $81 \%$ inhibition. The medium dose (5 $\mathrm{mg} / \mathrm{kg}$ ) had shown $75.05 \%$ inhibition efficacy comparable to the standard drug fluoxetine. The low dose and high doses had shown less efficacy compared to medium dose $(10 \mathrm{mg} / \mathrm{kg})$ test compound.

In TST model the percentage inhibition of protection against passive behaviour (immobility) was investigated. Fluoxetine produced $100 \%$ protection and test drug in high dose $(20 \mathrm{mg} / \mathrm{kg})$ had also produced $100 \%$ protection against passive behaviour comparably equal to fluoxetine. The medium dose test compound $(10 \mathrm{mg} / \mathrm{kg})$ had produced $83 \%$ protection against passive behaviour compared to fluoxetine. The low dose test compound (5 $\mathrm{mg} / \mathrm{kg}$ ) had produced $33.3 \%$ protection against passive 
behaviour. All doses have produced significant antidepressant activity and efficacy was proportionate to the dose against activity.

\section{CONCLUSION}

Results in FST model showed that the test compound at medium dose $(10 \mathrm{mg} / \mathrm{kg})$ showed significant diminution of immobility time (35 seconds) when compared to other groups. Similarly, in TST model also the animals that received medium dose $(10 \mathrm{mg} / \mathrm{kg})$ showed significant protection $(83.3 \%)$ against passive behaviour compared to other groups. These results specifies that compared to other two doses of test compound $(5 \mathrm{mg} / \mathrm{kg}$ and 20 $\mathrm{mg} / \mathrm{kg}$ ), medium dose of test compound can be effectively used for treating depression produced due to stress. Further study need to be extended for this compound to prove as a novel effective antidepressant compared to other drugs available for treating depression.

Funding: No funding sources

Conflict of interest: None declared

Ethical approval: The study was approved by the Institutional Ethics Committee

\section{REFERENCES}

1. Sindhu T, Mamatha A, Sahith Reddy K, Venkateshwarlu K. Antidepressant activity of pyrimidine derivatives in mice. $\mathrm{J}$ Drug Med. 2013;5:129-34.

2. Riyaz M, Kumar A, Raj V, Singh S. Review on antidepressant activity in behavioral models. Int $\mathrm{J}$ pharm Integrated Life Sci. 2013;1(3):16-29.

3. Dipiro T. Joseph Pharmacotherapy. A Pathophysiological Approach. 6th edition. McGrawHill medical publishing division; 2014; 1235-1256.

4. Baldessarini RJ. Drugs and the treatment of psychiatric disorders: Depression and anxiety disorders. In: Hardman JG, Limbrid LE, Goodman A, et al, editors. Goodman and Gilman's. The Pharmacological Basis of Therapeutics. $10^{\text {th }}$ ed. New York: McGraw-Hill; 2000:447-484.

5. Warner V, Weissman MM, Mufson L, Wickramaratne PJ. Grandparents, parents, and grandchildren at high risk for depression: Threegeneration study. J Am Acad Child Adolesc Psychiatry. 1999;38:289-96.
6. Kendler KS, Prescott CA. A population based twin study of lifetime major depression in men and women. Arch Gen Psychiatry. 1999;56:39-44.

7. Nutt DJ. Relationship of neurotransmitters to the symptoms of major depressive disorder. J Clin Psychiatry. 2008;69:4-7.

8. Vinayak M, Ruckmani A, Chandrashekar K, Konda VGR, Madhavi E, Swati B. Antidepressant activity of ethanolic extract Piper betle leaves in mice. Curr Res in Neurosci. 2012;2(1):11-6.

9. Singh GK, Garabadu D, Muruganandam AV, Joshi VK, Krishnamurthy S. Antidepressant activity of Asparagus racemosus in rodent models. Pharmacol Biochem Behav. 2009;91:283-90.

10. Shoeb A, Chowta M, Pallempati G, Rai A, Singh A. Evaluation of antidepressant activity of vanillin in mice. Indian J Pharmacol. 2013;45(2):141-4.

11. Porsolt RD, Bertin A, Jalfre M. Behavioral despair in mice: a primary screening test for antidepressants. Arch Int Pharmacodyn Ther. 1977;229:327-36.

12. Steru L, Chermat R, Thierry B, Simon P. The tail suspension test: a new method for screening antidepressants in mice. Psychopharmacol (Berl). 1985;85:367-70.

13. Ahmed Amany AE, Al-Rashed Nawal M, AlRasheed Nouf M. Antidepressant-like activities of rosiglitazone in the rat forced swim and the mouse tail suspension tests. Saudi Pharma J. 2009;1(17):5161.

14. Plaznik A, Tamborska E, Hauptmann M, Bidzinski A, Kostowski W. Brain neurotransmitter systems mediating behavioral deficits produced by inescapable shock treatment in rats. Brain Res. 1988;447:122-32.

15. Manavi C, Pinki V, Gautam P. Comparative evaluation of Bacopa monniera and Panax quniquefolium in experimental and depressive models in mice. Indian J Exp Biol. 2010;48:306-31.

16. Ramana Murty Kadali SLDV, Das MC, Srinivasa Rao ASR, Karuna Sri G. Antidepressant Activity of Brahmi in Albino Mice. J Clin Diagn Res. 2014;8(3):35-7.

Cite this article as: Jayakumar JK, Nityakarnam, Kumar KP, Supriya. Pharmacological evaluation of substituted 4, 5-diphenyl furan-3-carboxamide compound for antidepressant activity in mice. Int $\mathbf{J}$ Basic Clin Pharmacol 2017;6:39-42. 